\title{
PENERAPAN MODEL PEMBELAJARAN KOOPERATIF TIPE THINK PAIR SHARE (TPS) UNTUK MENINGKATKAN AKTIVITAS MATEMATIKA SISWA KELAS VII DI SMP NEGERI 1 KOTA BENGKULU
}

\author{
${ }^{1}$ Rizki Fadhillah, ${ }^{2}$ Della Maulidiya, ${ }^{3}$ Ringki Agustinsa \\ Universitas Bengkulu, FKIP, Prorgam Studi Pendidikan Matematika \\ email : ${ }^{1}$ fadhillahrizki4@gmail.com, ${ }^{2}$ della.maulidiya@unib.ac.id, ringki@unib.ac.id
}

\begin{abstract}
Abstrak
Penelitian ini bertujuan untuk meningkatkan aktivitas peserta didik kelas VII.3 SMP Negeri 1 Kota Bengkulu dalam pembelajaran Matematika dengan menerapakan model pembelajaran Pembelajaran kooperatif tipe Think Pair Share. Jenis penelitian ini adalah penelitian tindakan kelas (PTK) yang dilaksanakan dalam tiga siklus dengan alur penelitian yaitu perencanaan tindakan, pelaksanaan tindakan, pengamatan, dan refleksi. Subjek penelitian ini adalah peserta didik kelas VII.3 SMP Negeri 1 Kota Bengkulu Semester Genap Tahun Ajaran 2017/2018 dengan jumlah peserta didik terdiri dari 13 peserta didik laki-laki dan 20 peserta didik perempuan. Pengumpulan data dilakukan dengan menggunkan lembar observasi. Hasil penelitian menunjukkan Peningkatan aktivitas belajar peserta didik dapat dilihat dari skor rata-rata aktivitas peserta didik dari siklus I sampai siklus III, yaitu: 21; $28 ; 31$.
\end{abstract}

Kata Kunci: aktivitas, hasil belajar, model pembelajaran Think Pair Share

\begin{abstract}
This study aims to improve the activities of students of class VII.3 SMP Negeri 1 Kota Bengkulu in learning mathematics by applying the model of learning cooperative learning Think Pair Share type. This type of research is classroom action research (CAR) which is carried out in three cycles with the research flow that is action planning, action implementation, observation, and reflection. The subject of this research is the students of class VII.3 SMP Negeri 1 Kota Bengkulu Even Semester of the School Year 2017/2018 with the number of learners consists of 13 male students and 20 female students. Data collection is done by using observation sheet and end test cycle. The results showed that the learning activity of the students can be seen from the average score of the students' activity from cycle I to cycle III, namely: 21; 28; 31.
\end{abstract}

Keywords: activity, learning outcomes, learning model Think Pair Share

\section{PENDAHULUAN}

Pendidikan berperan penting dalam meningkatkan sumber daya manusia. Semakin baik kualitas pendidikan suatu negara semakin baik pula sumber daya manusia yang dihasilkan. Pendidikan adalah proses pemartabatan manusia menuju puncak optimasi potensi kognitif, afektif dan psikomotorik yang dimilikinya (Danim 2013: 3). Pendidikan merupakan aktivitas untuk mencapai suatu tujuan yang telah ditetapkan. Dengan pendidikan akan merubah cara berpikir karena dengan pendidikan akan mengubah orang yang tidak tahu menjadi tahu dan yang sudah tahu menjadi faham (Dimyati dan Mudjiono 2004:7). Matematika merupakan salah satu

Rizki, Della, Ringki 
bidang studi yang menduduki peran penting dalam dunia pendidikan, hal ini dapat dilihat dari waktu jam pelajaran sekolah lebih banyak dibandingkan pelajaran lain yaitu 5 jam pelajaran setiap minggu. Pada umumnya, matematika sering dianggap sebagai mata pelajaran yang sulit dipahami. Matematika merupakan ilmu yang sangat berperan dalam kehidupan manusia. Peranan tersebut berkaitan dengan penggunaan konsep-konsep matematika untuk menyelesaikan masalah dalam kehidupan sehari-hari. James dan James (Suherman dan Winatapura, 1992:120), mengatakan bahwa matematika adalah ilmu tentang logika mengenai bentuk, susunan, besaran, konsep konsep yang berhubungan satu dengan yang lainnya dengan jumlah yang banyak yang terbagi ke dalam tiga bidang, yaitu aljabar, analisis, dan geometri. Oleh sebab itu, matematika penting untuk dipelajari oleh setiap manusia mulai dari jenjang pendidikan di sekolah dasar sampai sekolah menengah atas bahkan perguruan tinggi.

Hasil observasi yang dilakukan di SMP Negeri 1 Kota Bengkulu yaitu pada saat kegiatan magang 3 yang dilakukan pada tanggal 20 Sepember 2017 diperoleh informasi bahwa siswa sulit memahami apa yag disampaikan guru, yang dialami tentunya berdampak pada hasil belajar yang belum memuaskan. Kegiatan observasi yang dilaksanakan pada saat proses pembelajaran berlangsung, pembelajaran yang dilaksanakan di SMP Negeri 1 Kota Bengkulu masih bersifat konvensional. Metode yang sering diterapkan oleh guru adalah metode ceramah, tanya jawab dan pemberian tugas sehingga siswa menjadi pasif dalam belajar. Selama ini dalam pembelajaran di kelas, siswa diberikan sedikit penjelasan tentang materi, lalu diberikan contoh dan diminta untuk menyelesaikan soal latihan. Siswa belum diberikan kesempatan aktif untuk saling berbagi informasi dan pengetahuan yang dimilikinya kepada siswa lainnya. Sehingga menyebabkan siswa belum aktif dalam kegiatan pembelajaran di kelas dan berdampak pada hasil belajar.

Data yang diperoleh pada saat observasi dari 33 siswa hanya 8 siswa aktif bertanya dan 5 siswa dapat menyelesaikan permasalahan yang diajukan oleh guru, sisanya hanya mendengarkan dan melihat temannya mengerjakan tanpa ikut aktif mengerjakan. Keadaan yang sama juga terjadi pada saat presentasi kelas hanya 6 siswa dari 33 yang mendengarkan sedangkan sisanya tidak mau mendengarkan penjelasan temannya di depan kelas dan berbicara diluar materi pelajaran serta ada siswa yang melamun serta ada yang mengerjakan tugas mata pelajaran yang lain. Selain itu penyebab dari tidak aktifnya siswa dalam pembelajaran yaitu model pembelajaran yang tidak menimbulkan aktivitas siswa dalam proses belajar matematika.

Salah satu metode yang dapat digunakan untuk memecahkan masalah tersebut adalah penerapan model pembelajaran kooperatif tipe Think Pair Share. Model pembelajaran Think Pair Share ini dikembangkan oleh Frank Lyman dan rekan-rekan dari Universitas Maryland. Trianto dalam Agustina (2007) menyatakan bahwa Pembelajaran kooperatif tipe Think Pair Share dapat melatih dan mengembangkan kemampuan berpikir serta aktivitas siswa, karena siswa membangun pengetahuan melewati eksplorasi dirinya sendiri dan pengetahuan siswa juga bisa berkembang melalui transfer pola pikir dengan siswa yang lain,sehingga siswa mampu menggabungkan dan membandingkan pola pikir mereka sendiri dengan pola pikir siswa yang lain.

Model pembelajaran kooperatif di harapkan merangsang kemampuan berpikir tingkat tinggi karena di sini potensi yang dimiliki oleh siswa benar-benar digali semaksimal mungkin. Selain itu kecakapan dan strategi mereka juga diuji, apa yang akan siswa lakukan terhadap masalah yang dia dapatkan tergantung pada pemikiran mereka sehingga diharapkan siswa dapat berpikir secara optimal.

Rizki, Della, Ringki 
Masalah diatas, maka diperlukan suatu alternatif pembelajaran yang dapat memberikan kesempatan kepada siswa untuk saling terlibat secara aktif dan bekerja sama dalam memecahkan masalah yang diberikan. Alternatif model pembelajaran yang sesuai dengan karakteristik masalah tersebut adalah model pembelajaran kooperatif tipe think pair share. Dengan menerapkan model pembelajaran kooperatif tipe think pair share memberi siswa kesempatan untuk bekerja sendiri serta bekerja sama dengan orang lain.

Upaya peningkatan aktivitas dan hasil belajar siswa dalam Mata Pelajaran Matematika dilakukanlah penelitian dengan judul "Penerapan Model Pembelajaran Kooperatif Tipe Think Pair Share (TPS) Untuk Meningkatkan Aktivitas dan Hasil Belajar Matematika Siswa Kelas VII Di SMP Negeri 1 Kota Bengkulu" khususnya pada materi segiempat dan segitiga.

\section{METODE}

Metode penelitian yang digunakan dalam penelitian ini adalah penelitian tindakan kelas (PTK). Sumadayo (2013:20) menyatakan penelitian tindakan kelas merupakan ragam penelitian pembelajaran yang berkonteks kelas yang dilaksanakan oleh guru untuk memecahkan masalah-masalah pembelajaran yang dihadapi oleh guru, memperbaiki mutu dan hasil pembelajaran dan mencobakan halhal baru pembelajaran demi peningatan mutu dan hasil pembelajaran. Sumadayo (2013:21) menyatakan bahwa ada tiga kata yang membentuk pengertian penelitian tindakan kelas yakni penelitian, tindakan, dan kelas.

\section{Tempat dan Waktu Penelitian}

Penelitian ini dilaksanakan di SMP Negeri 1 Kota Bengkulu yang beralamat di Jalan Jendral Sudirman, Kelurahan Tengah Padang, Kecamatan Teluk Segara, Kota Bengkulu, Bengkulu pada semester genap tahun pelajaran 2017/2018.

\section{Subjek Penelitian}

Subjek penelitian ini adalah siswa kelas VII.3 di SMP Negeri 1 Kota Bengkulu Tahun Pelajaran 2017/2018. Subjek penelitiannya adalah seluruh kelas VII.I SMP Negeri 1 Kota Bengkulu yang berjumlah 33 siswa, yang terdiri dari siswa laki-laki sebanyak 13 siswa dan siswa perempuan 20 .

\section{Prosedur Penelitian}

Penelitian yang dilaksanakan adalah Penelitian Tindakan Kelas (Classoom Action Research) yang dilaksanakan dalam 3 siklus. Setiap siklus terdiri dari empat tahap, yaitu 1) perencanaan (planing), 2) pelaksanaan (Action), 3) pengamatan (Observing), 4) refleksi (reflecting).

\section{a. Perencanaan Tindakan}

Adapun kegiatan yang dilakukan dalam tahap perencanaan adalah :

1) Mengidentifikasi masalah dan merumuskan masalah bersama guru mitra

2) Membuat Rencana Pelaksanaan Pembelajaran (RPP) dengan metode kooperatif tipe Think pair share

3) Membuat skenario pembelajaran

4) Membuat dan menyusun materi untuk siklus I

5) Membuat Lembar Kerja Peserta Didik (LKPD) dan kunci jawabannya

6) Menyusun lembar observasi untuk guru dan siswa

7) Menyusun alat evaluasi untuk melihat tingkat ketercapaian hasil belajar siswa. Alat evaluasi terdiri dari soal tes hasil belajar.

\section{b. Pelaksanaan Tindakan}

Pelaksanaan tindakan dilakukan sesuai dengan skenario pembelajaran dan RPP yang telah dibuat. Kemudian diadakan evaluasi pada akhir pertemuan dengan soal tes pada siklus I. Ini dilakukan untuk mengetahui sejauh mana pemahaman siswa atau hasil belajar siswa terhadap materi yang telah diajarkan.

Rizki, Della, Ringki 


\section{c. Pengamatan}

Observasi dilakukan untuk mengamati seluruh aktivitas guru dan siswa selama proses pembelajaran matematika berlangsung di kelas. Pengamatan dilakukan dengan menggunakan lembar observasi. Hasil observasi inilah yang nantinya akan digunakan pada tahap refleksi untuk perbaikan pada siklus berikutnya.

\section{d. Refleksi}

Berdasarkan hasil tes siswa, observasi aktivitas guru dan siswa yang telah dilakukan pada siklus I ini akan digunakan untuk merefleksikan diri. Kemudian, peneliti mengidentifikasi halhal yang sudah dan belum dicapai pada siklus I. Analisis pelaksanaan siklus I akan digunakan sebagai acuan untuk merencanakan tindakan dalam siklus berikutnya.

\section{Siklus II}

Siklus II dilaksanakan dengan melakukan perubahan pada bagianbagian tertentu yang didasarkan pada refleksi siklus I, sesuai dengan rencana pemeblajaran yang telah disusun. Langkah-langkah yang dilakukan pada siklus II sama halnya dengan siklus I.

\section{Siklus III}

Pelaksanaan proses pembelajaran pada siklus ketiga ini berdasarkan pada hasil refleksi siklus sebelumnya, yaitu pada siklus II dengan menggunakan langkah-langkah yang sama seperti pada siklus II.

\section{Instrumen Penelitian}

\section{Lembar Observasi aktivitas siswa}

Pengamatan atau observasi adalah suatu teknik yang dilakukan dengan cara mengadakan pengamatan secara teliti serta pencatatan secara sistematis. Lembar observasi digunakan untuk memperoleh data mengenai proses belajar mengajar selama penerapan model pembelajaran koopeatif tipe Think Pair Share menyangkut aktivitas siswa selama proses pembelajaran berlangsung. Hasil observasi dijadikan pedoman untuk perbaikan proses belajar mengajar pada siklus berikutnya. Akitivitas yang diamati dalam penelitian ini terdiri dari 12 butir, yaitu:

1. Peserta didik memperhatikan guru pada saat menjelaskan materi.

2. Peserta didik memahami masalah yang sedang dipelajari (Think)

3. Peserta didik memanfaat keterkaitan antara materi sebelumnya dengan materi yang sedang dipelajari saat ini.

4. Peserta didik berdiskusi secara berpasangan untuk menyelesaikan masalah yang ada pada Lembar Kerja Peserta Didik (Pair)

5. Peserta didik berintraksi antar anggota kelompok.

6. Peserta didik terlibat aktif dalam pembelajaran dengan berbicara, mengajukan pertanyaan, dan memberikan jawaban.

7. Peserta didik dapat mencari sumber untuk menyelesaikan masalah atau pertanyaan yang diberikan.

8. Peserta didik mampu membuat langkahlangkah peneyelesaian masalah yang ada pada Lembar Kerja Peserta Didik (LKPD)

9. Setiap kelompok mencatat data hasil diskusi ke lembar jawaban LKPD

10. Peserta didik menyampaikan hasil diskusi kelompok pada teman-teman sekelasnya (Share)

11. Peserta didik menyampaikan ide/pendapat pada saat diskusi berlangsung

12. Peserta didik meyampaikan kesimpulan tentang materi yang dipelajari pada pembelajaran

\section{Teknik Pengumpulan Data}

Observasi merupakan teknik mengumpulkan data dengan cara mengamati setiap kejadian yang sedang berlangsung dan mencatat tentang hal-hal yang akan diamati atau diteliti. Observasi digunakan untuk 
mengamati dan mendapatkan data tentang segala aktivitas guru dan aktivitas siswa selama proses pembelajaran berlangsung. Aktivitas belajar siswa yang diamati terdiri dari 12 butir aktivitas yang diamati oleh pengamat yaitu guru dan juga disesuaikan dengan langkahlangkah model pembelajaran kooperatif tipe think pair share.

\section{Teknik Analisis Data}

Data yang dikumpulkan menggunakan lembar observasi aktivitas siswa diolah secara deskriptif kuantitatif dengan menggunakan skala penilaian. Lembar observasi aktivitas siswa diolah dengan menggunakan persamaan berikut:

$\begin{gathered}\text { Kisaran nilai untuk tiap kriteria }= \\ (\text { Skor tertinggi }- \text { Skor terendah })+1\end{gathered}$
Sumber :

Modifikasi Sudijono ( 2008:330-331)

Keterangan:

Skor tertinggi $=$ jumlah butir observasi $\times$ skor tertinggi tiap butir observasi

Skor terendah $=$ jumlah butir observasi $\times$ skor terendah tiap butir observasi

Tabel 1. Kriteria Penilaian untuk Observasi Aktivitas Siswa

\begin{tabular}{|c|c|c|}
\hline Kriteria Penilaian & Notasi & Skor Nilai \\
\hline Kurang aktif & K & 1 \\
\hline Cukup aktif & C & 2 \\
\hline Aktif & B & 3 \\
\hline
\end{tabular}

Sumber : modifikasi dari Sudjana( 2006:77-78)

Lembar observasi aktivitas siswa berjumlah 12 butir observasi, skor tertinggi tiap butir observasi adalah 3, maka skor tertinggi adalah $3 \times 12=36$. Skor terendah tiap butir observasi adalah 1 , maka skor terendah adalah $1 \times 12=12$. Sehingga, kisaran untuk tiap kriteria adalah:

Kisaran nilai untuk tiap kriteria $=$ (Skor tertinggi-Skor terendah)+1 Banyaknya kriteria

$$
=\frac{(36-12)+1}{3}=\frac{25}{3}=8,334 \approx 8
$$

Kisaran nilai untuk tiap kriteria $=8$

Setelah diperoleh nilai rata-rata skor siswa maka kisaran skor penilaian untuk lembar observasi aktivitas siswa adalah:

Tabel 2. Kisaran Skor Lembar Observasi Aktivitas Siswa

\begin{tabular}{|c|c|}
\hline Kriteria Penilaian & Kisaran Skor \\
\hline Kurang aktif & $12 \leq x<20$ \\
\hline Cukup aktif & $20 \leq x<28$ \\
\hline Aktif & $28 \leq x \leq 36$ \\
\hline
\end{tabular}

Keterangan: $\mathrm{x}=$ nilai skor aktivitas siswa

Tabel 3. Interval Kategori Penilian Aktivitas untuk Aspek yang Diamati

\begin{tabular}{|c|c|}
\hline Interval & Kategori penilaian \\
\hline $1 \leq x<1,67$ & Kurang Aktif \\
\hline $1,67 \leq x<2,34$ & Cukup Aktif \\
\hline $2,34 \leq x \leq 3$ & Aktif \\
\hline
\end{tabular}

\section{Indikator Kerberhasilan}

Tindakan diberhentikan jika kriteria keberhasilan tindakan telah tercapai. Kriteria keberhasilan tindakan penelitian adalah aktivitas siswa dikatakan meningkat jika hasil lembar observasi aktivitas siswa secara umum mencapai skor antara 28-36 dengan kategori Aktif.

\section{HASIL DAN PEMBAHASAN Hasil Penelitian}

Penelitian tindakan kelas ini dilakukan dengan menerapkan pendekatan pembelajaran saintifik yang terintegrasi dengan model pembelajaran Think-Pair-Share. Hasil penelitian yang diperoleh selama tiga siklus mencakup empat tahapan, yaitu : 1)Perencanaan, 2)Pelaksanaan, 3) Pengamatan, 4) Refleksi.

\section{Kondisi Awal}

Sebelum melakukan tindakan, peneliti terlebih dahulu melaksanakan refleksi awal

Rizki, Della, Ringki 
yang dilakukan melalui observasi ke kelas VII.3 SMP Negeri 1 Kota Bengkulu pada hari selasa 13 Maret 2018. Selain itu, peneliti juga mewawancarai guru matematika yang mengajar di kelas VII.3 SMP Negeri 1 Kota Bengkulu. Berdasarkan hasil wawancara dan observasi pembelajaran di kelas, dapat dikemukakan gambaran umum permasalahan yang dihadapi guru dalam proses pembelajaran matematika di kelas VII.3 SMP Negeri 1 Kota Bengkulu sebagai berikut:

1. Pembelajaran di kelas masih bersifat berpusat pada guru sehingga keterlibatan siswa dalam proses pembelajaran kurang optimal dan siswa menjadi pembelajar pasif.

2. Terdapat beberapa peserta didik yang kurang memperhatikan guru ketika pembelajaran matematika berlangsung. Ketika ditanya mengerti atau tidak semua siswa menjawab mengerti pada materi yang dijelaskan. Namun, ketika ditanya satu-persatu siswa mengenai materi yang dijelaskan, masih banyak yang kesulitan menyampaikan pendapatnya.

\section{Observasi Aktivitas Peserta didik Siklus I Observasi Aktivitas Siswa Siklus I}

Hasil observasi siklus I dalam kegiatan pembelajaran dengan penerapan model pembelajaran kooperatif tipe think pair share terdapat dua belas indikator penilaian yang ada di dalam lembar observasi siswa, hasil rata-rata penilaian oleh pengamat adalah 21 termasuk kriteria aktivitas siswa cukup aktif. Beberapa kelompok sudah melakukan kegiatan pembelajaran dengan baik, sedangkan kelompok lain belum mempunyai kemauan untuk mengerjakan tugas dan sibuk menggangu teman anggota kelompok disebelahnya.

\footnotetext{
Selain observer yang melakukan pengamatan, peneliti juga melakukan pengamatan selama berlangsungnya pembelajaran pada siklus I. Pada siklus I, selain masih banyak siswa yang belum terlibat ketika
}

melakukan diskusi kelompok, terdapat juga siswa yang mengobrol dengan leluasa ketika guru memberikan arahan untuk melakukan diskusi. Untuk menanggulangi hal ini, guru memberikan teguran kepada siswa yang bersangkutan. Selain itu, siswa tersebut juga diminta untuk menyampaikan kembali apa yang telah disampaikan oleh guru.

\section{Refleksi Siklus I}

Hal-hal yang telah dicapai pada siklus I dalam proses pembelajaran menggunakan model pembelajaran kooperatif tipe think pair share sebagai berikut untuk aktivitas belajar peserta didik, pembelajaran di kelas sudah membuat siswa lebih aktif karena menggunakan model pembelajaran kooperatif tipe think pair share yang mengharuskan siswa mampu menganalisis, mengamati dan menyimpulkan hasil pengamatan secara individu. Walaupun pada pelaksanaannya siswa masih banyak yang bingung mengerjakan LKPD. Dan Siswa tertarik dengan kegiatan mengukur sudut dan panjang menggunakan busur dan penggaris secara langsung sehingga mereka dapat mengetahui kenapa suatu sudut atau sisi dapat dikatakan sama atau tidak. Meskipun masih banyak siswa yang belum bisa menggunakan penggaris dan busur secara benar.

1. Siswa masih kesulitan menggunakan busur dan penggaris. Sehingga waktu yang digunakan untuk mengamati gambar bangun datar dengan cara mengukur sudut dan panjang sisinya menggunakan busur dan penggaris memotong waktu untuk presentasi Kegiatan diskusi pada kelompok tertentu hanya dilakukan oleh salah satu peserta didik.

2. Kegiatan diskusi yang efektif belum tercapai karena ada beberapa siswa yang ribut.

3. Siswa masih kesulitan mengemukakan pendapat dengan kata-kata sendiri, sehingga jika ditanya masih banyak yang diam. 
Beberapa siswa belum berani untuk presentasi didapat bahwa pada siklus I masih belum berhasil, karena belum memenuhi kriteria ketuntasan yang telah ditetapkan. Oleh sebab itu tidakan perlu dilanjutkan pada siklus II dengan perbaikan yang harus dilakukan. Upaya yang perlu dilakukan peneliti untuk perbaikan pada siklus II antara lain:

1. Membagi ulang beberapa pasangan, karena ada pasangan yang mengalami masalah.

2. Sebelum melakukan kegiatan guru meminta peserta didik untuk membaca panduan LKPD yang diberikan.

3. Setelah melakukan kegiatan guru menyampaikan materi pada pertemuan selanjutnya agar lebih paham.

4. Guru memberikan teguran kepada peserta didik yang melakukan aktivitas yang tidak diminta oleh guru, misalnya mengobrol dengan pasangan lain.

\section{Hasil observasi aktivitas siklus II}

Hasil observasi siklus II dalam kegiatan pembelajaran dengan penerapan model pembelajaran kooperatif tipe think pair share terdapat dua belas indikator penilaian yang ada di dalam lembar observasi siswa, hasil rata-rata penilaian oleh pengamat adalah 28 termasuk kriteria aktivitas siswa aktif. Beberapa kelompok sudah melakukan kegiatan pembelajaran dengan baik, sedangkan kelompok lain belum mempunyai kemauan untuk mengerjakan tugas dan sibuk menggangu teman anggota kelompok disebelahnya.

$\begin{array}{cccr}\text { Selain } & \text { observer } & \text { yang } & \text { melakukan } \\ \text { pengamatan, } & \text { peneliti } & \text { juga } & \text { melakukan } \\ \text { pengamatan } & \text { selama } & \text { berlangsungnya }\end{array}$
pembelajaran pada siklus II. Pada siklus II, selain masih banyak siswa yang belum terlibat ketika melakukan diskusi kelompok, terdapat juga siswa yang mengobrol dengan leluasa ketika guru memberikan arahan untuk melakukan diskusi. Untuk menanggulangi hal ini, guru memberikan teguran kepada siswa yang bersangkutan. Selain itu, siswa tersebut juga diminta untuk menyampaikan kembali apa yang telah disampaikan oleh guru.

\section{Refleksi Siklus II}

Berdasarkan hasil diatas, didapat bahwa pada siklus I masih belum berhasil, karena belum memenuhi kriteria ketuntasan yang telah ditetapkan. Oleh sebab itu tidakan perlu dilanjutkan pada siklus III dengan perbaikan yang harus dilakukan. Upaya yang perlu dilakukan peneliti untuk perbaikan pada siklus II antara lain:

1. Guru memberikan teguran kepada peserta didik yang melakukan aktivitas yang tidak diminta oleh guru, misalnya mengobrol dengan pasangan lain.

2. Sebelum melakukan kegiatan guru meminta peserta didik untuk membaca panduan LKPD yang diberikan.

3. Setelah melakukan kegiatan guru menyampaikan materi pada pertemuan selanjutnya agar lebih paham.

\section{Observasi Aktivitas Peserta didik Siklus III}

Hasil observasi siklus III dalam kegiatan pembelajaran dengan penerapan model pembelajaran kooperatif tipe think pair share terdapat dua belas indikator penilaian yang ada di dalam lembar observasi siswa, hasil rata-rata penilaian oleh pengamat adalah 31 termasuk kriteria aktivitas siswa aktif. Semua kelompok sudah melakukan kegiatan pembelajaran dengan baik, mempunyai kemauan untuk mengerjakan tugas dan tidak menggangu teman anggota kelompok disebelahnya. Selain observer yang melakukan pengamatan, peneliti juga melakukan pengamatan selama berlangsungnya pembelajaran pada siklus III. Pada siklus III, banyak siswa yang terlibat ketika melakukan diskusi kelompok, tidak banyak terdapat siswa yang mengobrol dengan leluasa ketika guru memberikan arahan untuk melakukan diskusi.

Perkembangan rata-rata skor aktivitas peserta didik setiap aspeknya dari siklus I 
hingga siklus III dapat dilihat pada gambar berikut ini.

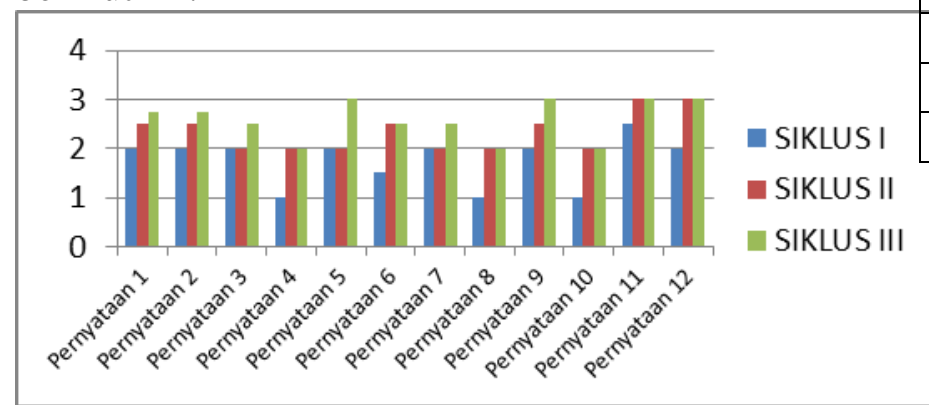

Gambar diatas menunjukkan bahwa aktivitas peserta didik setiap aspeknya ada yang mengalami peningkatan dan tidak ada aktivitas peserta didik yang mengalami penurunan. Peningkatan aktivitas peserta didik ini dikarenakan peneliti selalu melakukan tindakan perbaikan pada setiap aspek yang masih kurang. Gambar 4.3 menunjukkan perkembangan setiap skor rata-rata observasi aktivitas peserta didik setiap pernyataan selalu meningkat setiap siklusnya. Peningkatan skor hampir terjadi di setiap penyataan. Terdapat beberapa pernyataan yang tidak mengalami peningkatan yaitu pernyataan 4,6,8,dan 10 hal tersebut dikarnakan beberapa peserta didik yang belum bisa bekerja sama dalam kelompok dan sulit untuk meyampaikan pendapat mereka masing-masing sehingga pernyataan tersebut tidak mengalami peningkatan.

Guru telah memberikan motivasi agar peserta didik lebih berani dan mau bekerjasama dengan baik terhadap teman kelompoknya. Tidak hanya motivasi yang disampaikan kepada peserta didik, guru juga memberikan motivasi dalam bentuk hadiah yaitu tambahan nilai agar peserta didik lebih bersemangat dalam melakukan kegiatan pembelajaran khususnya pada saat presentasi di depan kelas.

Hasil pengamatan aktivitas peserta didik secara keseluruhan dapat dilihat pada tabel berikut ini :

Tabel 4. Rekapitulasi Hasil Observasi Aktivitas Peserta didik Setiap Siklus

\begin{tabular}{|c|c|c|}
\hline Siklus & $\begin{array}{l}\text { Rata-rata } \\
\text { Skor }\end{array}$ & Kriteria \\
\hline $\mathrm{I}$ & 21 & Cukup akif \\
\hline II & 28 & Aktif \\
\hline III & 31 & Aktif \\
\hline
\end{tabular}

Berdasarkan hasil pengamatan aktivitas peserta didik secara keseluruhan seperti yang terlihat pada tabel diatas dapat diketahui bahwa aktivitas peserta didik secara keseluruhan meningkat dari siklus I hingga siklus III. Pada siklus I, aktivitas peserta didik berada pada kriteria cukup aktif dengan rata-rata skor 21 . Pada siklus II, aktivitas peserta didik sudah mengalami peningkatan tetapi belum optimal. Rata-rata skor aktivitas peserta didik siklus II adalah 28 dan masih berada pada kriteria cukup aktif. Pada siklus III, rata-rata skor aktivitas peserta didik meningkat menjadi 31 dan berada pada kriteria Aktif.

\section{PEMBAHASAN}

Penelitian Tindakan Kelas ini dilaksanakan di SMP Negeri 1 Kota Bengkulu selama tiga siklus. Peneliti berupaya meningkatkan aktivitas belajar peserta didik melalui penerapan model pembelajaran kooperatif tipe Think Pair Share.

\section{Analisis Cara-cara Peningkatan Aktivitas belajar}

Pengamatan aktivitas peserta obeservasi pengamat dengan melihat lembar pernyataan. Pernyataan didasarkan dengan langkah-langkah model pembelajaran kooperatif tipe think pair share yang diamati oleh pengamat untuk setiap siklusnya. Peningkatan aktivitas peserta didik yang diamati pada setiap tahapan pembelajaran kooperatif tipe think pair share sebagai berikut. 1. Tahap think

Siklus I, beberapa peserta didik belum memperhatikan dan mendengarkan penjelasan yang disampaikan peneliti. Pada tahap ini beberapa peserta didik tidak mengerjakan LKPD dengan baik, sehingga peserta didik

Rizki, Della, Ringki

Penerapan Model Pembelajaran Kooperatif Tipe Think Pair Share (TPS) Untuk Meningkatkan Aktivitas Matematika Siswa Kelas VII Di SMP Negeri 1 Kota Bengkulu 
tidak melakukan aktivitas dengan maksimal. Peserta didik hanya duduk diam dan tidak menanggapi pertanyaan yang terdapat pada LKPD.sambil menanggu temannya. Pada siklus II, aktivitas di tahap think mengalami peningkatan, peseta didik yang mengobrol dan mengganggu temannya sudah berkurang. Peserta didik fokus mengerjakan LKPD yang diberikan dan mendengarkan penjelasan guru. Sedangkan di siklus III, hampar semua peserta didik melakukan kegiatan yang ada di tahap think. Ketika guru memberikan pernyataan banyak menaggapi, bahkan peserta didik yang sering mengobrol dan menganggu temanya juga menangapi penyaataan yang guru sampaikan.

2. Tahap pair

Siklus I aktivitas yang dilakukan peserta didik masih cukup aktif, dilihat dari pengamatan yang dilakukan pengama dan peneliti, hanya beberapa kelompok yang benarbenar melakukan kagiatan berdiskusi bertukar pikiran, sedangkan kelompok lainnya sibuk mengerjakan secara individu bahkan ada kelompok yang tidak mengerjakan sama sekali. Pada siklus II aktivitas yang dilakukan peserta didik sudah mulai meningkat, sekitar 10 kelompok sudah melakukan kegiatan dengan baik, ada juga peserta didik yang bertanya bagaimana cara mengerjakan soal latihan yang diberikan. Pada siklus III setiap kelompok menyelesaikan kegiatan di tahap pair dengan baik.

\section{Tahap Share}

Siklus I tahap ini, aktivitas yang dilakukan peserta didik masih belum tampak. Banyak perserta didik yang belum berani manyampaikan pendapatnya di depan kelas dan masih malu-malu untuk karena takut diganggu oleh teman-teman-temannya. Sehingga guru menunjuk beberapa kelompok untuk melekukan presentasi didepan kelas. Untuk siklus II, aktivitas yang dilakukan peserta didik sudah mulai meningkat, mereka mengajukan diri unuk mempresentasikan hasil kerja kelompok mereka dan yang menanggapi serta memberikan saran saat jalannya diskusi sudah ada beberapa peserta didik. Aktivitas peserta didik pada siklus III semakin baik. Sebagian besar peserta didik sudah memperhatikan dan mendengarkan penjelasan dari kelompok lain yang sedang melakukan presentasi serta semakin banyak peserta didik yang antusias dalam menanggapi pertanyaan peneliti.

Pengamatan aktivitas peserta didik dilakukan dengan melihat lembar pengamatan yang terdiri dari 12 butir pernyataan. Pernyataan didasarkan dengan langkah-langkah model pembelajaran kooperatif tipe think pair share yang diamati oleh pengamat untuk setiap siklusnya. Aktivitas peserta didik pada sub bab pembahasan ini dianalisis berdasarkan lembar observasi pengamatan. Kriteria masing-masing pernyataan adalah kurang, cukup, dan baik. Pada siklus I diperoleh aktivitas peserta didik mendapat skor rata-rata dari kedua pengamat yaitu 21 dengan kriteria cukup aktif. Analisis aktivitas peserta didik untuk siklus I, siklus II dan siklus III diketahui bahwa pada pernyataan 4, 6, 8, dan 10 memiliki skor rata-rata dibawah 2 atau tidak mengalami peningkatan pada siklus sebelumnya dengan kriteria kurang aktif.

Faktor yang menyebabkan pernyataan 4 belum mencapai kriteria baik atau tidak mengalami peningkatan yaitu aktivitas peserta didik belum belum serius berdiskusi secara berpasangan karena masih banyak peserta didik yang sibuk dengan kegiatan seperti mengobrol dan menganggu temannya. Selain pernyataan 4 , pernyataan 6 juga belum mencapai kriteria baik atau tidak mengalami peningkatan yaitu peserta didik masih tidak percaya diri untuk menyampaikan tanggapan atau gagasan dengan teman-teman satu kelompok atau pada saat diskusi berlangsung. Penyebab pernyataan 8 belum mencapai kriteria baik belum paham bagaimana mengerjakan LKPD yang diberikan sehingga peserta didik belum mampu membuat langkah-langkah penyelesaian masalah.

Cara-cara yang dilakukan untuk meningkatkan aktivitas ini yaitu menegur, dan memotivasi. Apabila peserta didik masih

Rizki, Della, Ringki 
melakukan kegiatan lain sehingga mengahambat jalanya kegiatan pembelajaran maka yang dilakukan guru dengan ketempat duduknya dan menegurnya. Hal tersebut dilakukan agar peserta didik tidak mengulangi perbuatannya. Selain itu, Pemberian motivasi akan mendorong peserta didik untuk melakukan suatu kegiatan karena belajar sangat membutuhkan adanya motivasi. Tidak hanya motivasi yang disampaikan kepada peserta didik, guru juga memberikan motivasi dalam bentuk hadiah yaitu tambahan nilai agar peserta didik lebih bersemangat dalam melakukan kegiatan pembelajaran khususnya pada saat presentasi di depan kelas.

Hasil analisis terhadap hasil penelitian diperoleh pada siklus I aktivitas yang dilakukan peserta didik berada pada kriteria cukup aktif dengan skor rata-rata 21 mengalami peningkatan menjadi 28 dan pada siklus III aktivitas yang dilakukan peserta didik berada pada kriteria aktif dengan skor rata-rata 30. Peningkatan aktivitas peserta didik ini dikarenakan peneliti selalu melakukan tindakan perbaikan pada setiap pernyataan khususnya pada tindakan masih kurang pada setiap siklusnya. Berdasarkan hasil penelitian dengan tindakan yang dilakukan di kelas VII 3 menyebabkan aktivitas belajar peserta didik mengalami peningkatan.

\section{PENUTUP}

\section{Simpulan}

Berdasarkan hasil penelitian yang telah dilaksanakan di kelas VII.3 SMP Negeri 1 Kota Bengkulu dengan tindakan yang dilakukan, yaitu:

\section{Aktivitas Belajar}

a) Peserta didik diatur dalam kelompok belajar yang terdiri dari 2 orang atau lebih dan berbeda setiap siklus berdasarkan hasil belajar dan tempat duduknya untuk meningkatkan keaktifan kegiatan diskusi kelompok,

b) Memberikan teguran dan perhatian oleh guru dimana perhatian tersebut diberikan kepada peserta didik yang kurang serius dan masih bermain-main serta mengganggu teman kelompoknya maupun kelompok lain,

c) Memberikan motivasi yang mengalami kesulitan dalam menyampaikan pendapat saat diskusi di kelas.

Tindakan tersebut menyebabkan terjadinya peningkatan aktivitas peserta didik dengan skor rata-rata pengamatan aktivitas peserta didik pada siklus I adalah 21 pada kriteria cukup aktif, pada siklus II meningkat sebesar 28 pada kriteria aktif meningkat menjadi pada siklus III adalah 30 dengan kriteria aktif.

\section{Saran}

Berdasarkan penelitian yang telah dilaksanakan peneliti, terdapat beberapa saran yang diberikan sebagai berikut :

1. Guru mata pelajaran matematika sebaiknya menerapkan model pembelajaran kooperatif tipe Think Pair Share dengan bantuan lembar kerja peserta didik pada pokok bahasan yang cocok sebagai variasi model pembelajaran sehingga peserta didik tidak merasa bosan.

\section{DAFTAR PUSTAKA}

Agustina, Hertika dkk.Penerapan Model Pembelajaran Kooperatif Tipe Think Pair Share untuk Meningkatkan Aktivitas Belajar Siswa pada Materi Fungsi Kelas Viii E Smp Negeri 2 Malang.Universitas Negeri Malang

\section{A.M, Sardiman. 2008. Interaksi dan Motivasi Belajar Mengajar.Jakarta: PT Raja Grafindo Persada}

Azizah, Nur.2008. Model pembelajaran kooperatif tipe think pair share untuk aktivitas siswa dan hasil belajar matematika anak tunarungu:Sidoarjo. Jurnal Pendidikan Luar Biasa.Vol.4, No.1. 
Danim, sudarwan.2013. penghantar pendidikan. Bandung:ALFABETA

Darmawan, Deni dan Permasih. 2011. Kurikulum dan Pembelajaran: Bandung.Raja Grafindo Perseda

Dimyati dan mudjiono. 1994. Belajar dan Pembelajaran. Jakarta: Departemen Pendidikan dan Kebudayaan

Evie, Marinus dan Putu, Ni.2015.Penerapan Model Pembelajaran Kooperatif Tipe Think Pair Share (TPS) untuk Meningkatkan Hasil Belajar Siswa pada Materi Pemfaktoran Bentuk Aljabar Di Kelas VIII SMPN 20 Palu.vol.4, no 1.

Hudojo, Herman. 2005. Pengembangan Kurikulum dan Pembelajaran Matematika. Malang: UM Press.

Isjoni. 2016. Cooperative Learning. Bandung:ALFABETA

Kurniasih, Imas dan Sani, Berlin.2016.Ragam Pengenbangan Model Pembelajaran.Jakarta:Kata Pena

Melyawati.2014.Penerapan Model Pembelajaran Kooperatif Tipe Think Pair Share (TPS) untuk Meningkatkan Hasil Belajar Siswa pada Operasi Hitung Bentuk Aljabar Di SMP Negeri 13 Palu.vol.2,no.1.

Rusman. 2013. Model-model Pembelajaran Berorientasi Standar Proses Pendidikan. Jakarta : Raja grafindo perseda

Soedjadi, R. 2000. Kiat Pendidikan Matematika di Indonesia. Jakarta: Depdiknas

Sudjana, Nana. 2016. Penilaian Hasil Proses Belajar Mengajar.Bandung: Remaja Rosdakarya

Suherman, Erman dan Winatapura, Udin S. 1992. Strategi Belajar Mengajar
Matematika. Jakarta: Departemen Pendidikan Dan Kebudayaan

Sumadayo, Samsu.2013. Penelitian Tindakan Kelas.Yogyakarta: Graha Ilmu

Suprijono, Agus. 2014. Cooperative Learning. Yogyakarta: Pustaka Belajar

Tahir, Wahdah M. 2012. Peningkatan Aktivitas Belajar Siswa Menggunakan Media Kartu Bilangan pada Pembelajaran Matematika. Universitas Tanjungpura

Thobroni, M. 2016. Belajar dan Pembelajaran. Yogyakarta: Ar-Ruzz Media

Zulkarnain, Iskandar dan Djamilah, Soraya.2015. Penerapan model pembelajaran think pair share terhadap kemampuan pemahaman matematis siswa sekolah menengah pertama:Banjarmasin. Jurnal Pendidikan Matematika.Vol.3, No.1.

Rizki, Della, Ringki

Penerapan Model Pembelajaran Kooperatif Tipe Think Pair Share (TPS) Untuk Meningkatkan

Aktivitas Matematika Siswa Kelas VII Di SMP Negeri 1 Kota Bengkulu 